\title{
IMPLEMENTASI PAKET SHINY PADA PEMODELAN MULTISCALE AUTOREGRESSIVE UNTUK DATA HARGA SAHAM BBRI
}

\author{
Bahtiar Ilham Triyunanto ${ }^{1}$, Suparti², Rukun Santoso ${ }^{3}$ \\ ${ }^{1,2,3}$ Departemen Statistika, Fakultas Sains dan Matematika, Universitas Diponegoro \\ bahtiarilham45@gmail.com
}

\begin{abstract}
Stocks are an investment that attract people because they can earn large profits by having claim rights to the company's income and assets so investors have to observe stock price movements in the future to achieve investment goals. One of the statistical methods for time series data modeling is ARIMA. However, modeling assumptions must be fulfilled to use that method so an alternative model is proposed, namely nonparametric regression model, which has no modeling assumptions requirement. In this study, the nonparametric regression multiscale autoregressive (MAR) with two different filter and decomposition level $\mathbf{J}$ are compared to choose the best model and forecast it. The data are closing stock price, high stock price and low stock price of BBRI's stocks that divided into 2 parts, namely in sample data from March 19, 2020 to February 4, 2021 to form a model and out sample data from February 5, 2021 to March 23, 2021 used for evaluation of model performance based on MAPE values. The chosen best model for each stock price are the MAR model with wavelet haar filter and decomposition level 5 for the closing stock price which produces a MAPE value of $1.194 \%$, the MAR model with wavelet haar filter and decomposition level 5 for the high stock price which produces a MAPE value of $1.283 \%$, and the MAR model with a wavelet haar filter and decomposition level 5 for the low stock price which produces a MAPE value of $1.141 \%$, indicating that the models have excellent forecasting capability. In this study, Graphical User Interface (GUI) using R software with the help of shiny package is also built, making data analyzing easier and generating more interactive display output.
\end{abstract}

Keywords: Stocks, wavelet transformation, MAR, MAPE, GUI

\section{PENDAHULUAN}

Saham merupakan salah satu jenis efek atau surat berharga yang umumnya dijual di pasar modal. Perusahaan yang perkembangannya baik umumnya akan memberikan hasil investasi (Tandelilin, 2010). Saham menjadi pilihan investasi yang menarik karena dapat memperoleh untung yang besar yaitu memiliki hak klaim atas penghasilan dan aktiva perusahaan serta dapat menjadi penghasilan utama saat masa pensiun atau menjelang hari tua nanti sehingga banyak orang mulai tertarik menananmkan saham.

Dalam menanam saham, pengguna tidak ingin salah dalam menanam saham yang mengakibatkan kerugian. Oleh karena itu pergerakan saham perlu diamati sehingga dapat menentukan waktu yang tepat untuk menanam saham. 
Ada banyak model yang digunakan untuk memprediksi masa yang akan datang, salah satu model yang umum digunakan adalah model ARMA. Namun pada pemodelan ARMA terdapat asumsi-asumsi yang harus dipenuhi yaitu stasioneritas, normalitas residual, nonautokorelasi residual, dan homoskedastisitas residual. Sehingga digunakan model alternatif regresi nonparametrik yang tidak terikat asumsi pemodelan.

Salah satu metode regresi nonparametrik yaitu multiscale autoregressive (MAR). Model MAR diadaptasi dari model runtun waktu AR dengan input yang digunakan adalah koefisien wavelet dan skala yang diperoleh dengan mendekomposisi menggunakan maximum overlap discrete wavelet transformation (MODWT). Perhitungan MAR termasuk rumit sehingga dibutuhkan Graphical User Interface (GUI) untuk memudahkan pengguna dalam analisis data dan menampilkan output yang lebih menarik.

Tujuan penelitian ini adalah untuk mengetahui kinerja dari model MAR menggunakan kriteria MAPE out sample dan melakukan forecasting data harga saham BBRI harian yang meliputi harga penutupan, harga tertinggi dan harga terendah sehingga pengguna dapat menentukan waktu yang tepat untuk menanam saham.

\section{TINJAUANPUSTAKA}

\subsection{Harga Saham}

Harga saham merupakan salah satu indikator yang digunakan untuk menilai berhasil atau tidaknya perusahaan dalam mengelola usaha miliknya. Semakin naiknya harga saham perusahaan di bursa efek akan meningkatkan kepercayaan investor terhadap modal yang telah dikeluarkan investor tersebut. Sebaliknya, semakin rendah harga saham perusahaan tersebut dibursa efek maka akan mengurangi kepercayaan investor akan nilai perusahaan (Zuliarni, 2012)

\subsection{Analisis Runtun Waktu}

Analisis runtun waktu (time series) adalah sebuah metode statistik yang dipakai untuk menemukan pola data di masa lalu yang dapat digunakan untuk meramalkan pola data di masa yang akan datang. Salah satu model yang umum digunakan adalah model ARIMA. Model ARIMA (p,d,q) secara umum ditulis dalam persamaan matematis sebagai berikut

$$
\phi_{p}(B)(1-B)^{d} Z_{t}=\theta_{q} A_{t}
$$

\subsection{Fungsi wavelet}

Fungsi wavelet merupakan fungsi matematika yang mempunyai sifat-sifat tertentu, antara lain berosilasi disekitar nol, terlokalisasi dalam domain waktu dan frekuensi serta membentuk sebuah basis ortogonal dalam $L^{2}(R)$ (Lestari dan Subanar, 2015). Fungsi wavelet dibedakan atas dua fungsi, yaitu wavelet ayah $(\phi)$ dan wavelet ibu $(\psi)$ yang memiliki sifat sebagai berikut:

$$
\int_{-\infty}^{\infty} \phi(x) d x=1 \quad \text { dan } \quad \int_{-\infty}^{\infty} \psi(x) d x=0
$$

Dengan gabungan proses dilatasi penskalaan dan proses translasi atau pergeseran posisi menghasilkan jenis wavelet ortogonal, yaitu:

$$
\phi_{j, k}(x)=2^{-j / 2} \phi\left((2)^{-j} x-k\right) \quad \text { dan } \psi_{j, k}(x)=2^{-j / 2} \psi\left((2)^{-j} x-k\right)
$$




\subsection{Transformasi Wavelet Diskrit}

Transformasi wavelet diskrit (DWT) merupakan salah satu cara yang dapat digunakan untuk menghitung koefisien dari aproksimasi barisan wavelet. Secara sistematis DWT dapat dituliskan sebagai berikut:

$$
\mathbf{w}=\mathbf{W X}
$$

dengan:

w : koefisien DWT

W : matriks transformasi berukuran nxn

matriks transformasi $\mathbf{W}$ dibentuk dengan translasi dan dilatasi filter $\mathbf{h}$ dan dan $\mathbf{g}$ yang diberikan dengan tetap mempertahankan sifat-sifat filter pada setiap operasi translasi dan dilatasi.

$$
\mathrm{W}=\left[\begin{array}{cccccccc}
h_{1}^{(1)} & h_{0}^{(1)} & 0 & \ldots & 0 & h_{L-1}^{(1)} & \ldots & h_{2}^{(1)} \\
h_{3}^{(1)} & h_{2}^{(1)} & h_{1}^{(1)} & h_{0}^{(1)} & 0 & \ldots & h_{5}^{(1)} & h_{4}^{(1)} \\
\ldots & \ldots & \ldots & \ldots & \ldots & \ldots & \ldots & \ldots \\
0 & 0 & \ldots & h_{L-1}^{(1)} & h_{L-2}^{(1)} & \ldots & h_{1}^{(1)} & h_{0}^{(1)} \\
h_{3}^{(2)} & h_{2}^{(2)} & h_{1}^{(2)} & h_{0}^{(2)} & \ldots & h_{3 L-2}^{(2)} & \ldots & h_{4}^{(2)} \\
\ldots & \ldots & \ldots & \ldots & \ldots & \ldots & \ldots & \ldots \\
h_{2}^{(J)} & h_{2^{\prime}-2}^{(J)} & \ldots & \ldots & \ldots & \ldots & h_{1}^{(J)} & h_{0}^{(J)} \\
g_{2^{\prime}-1}^{(J)} & g_{2^{\prime}-2}^{(J)} & \ldots & \ldots & \ldots & \ldots & g_{1}^{(J)} & g_{0}^{(J)}
\end{array}\right]
$$

\subsection{Maximal Overlap Discrete Wavelet Transformation}

Maximal Overlap Discret Wavelet Transform (MODWT) dapat mengeliminasi reduksi data menjadi setengahnya (down-sampling) sehingga dalam setiap level akan terdapat koefisien wavelet dan skala sebanyak panjang data (Percival dan Walden, 2000) sehingga lebih sesuai untuk pemodelan pada time series dibandingkan dengan DWT. Secara sistematis MODWT dapat dituliskan sebagai berikut:

$$
\tilde{\mathrm{W}}=\tilde{\mathrm{W} X}
$$

dengan:

$\widetilde{\mathrm{w}} \quad$ : koefisien wavelet MODWT pada level ke j

$\tilde{\mathrm{W}} \quad$ : matriks transformasi MODWT berukuran nxn

Dengan mendefinisikan $\tilde{\mathrm{V}}$ yang merupakan matriks NxN yang berisikan filter $\tilde{g}$ dan $\tilde{\mathrm{W}}$ adalah matriks NxN yang berisikan filter $\tilde{h}$, sehingga diperoleh matriks filter wavelet $\tilde{\mathrm{W}}$ dan matriks filter skala $\tilde{\mathrm{V}}$ sebagai berikut:

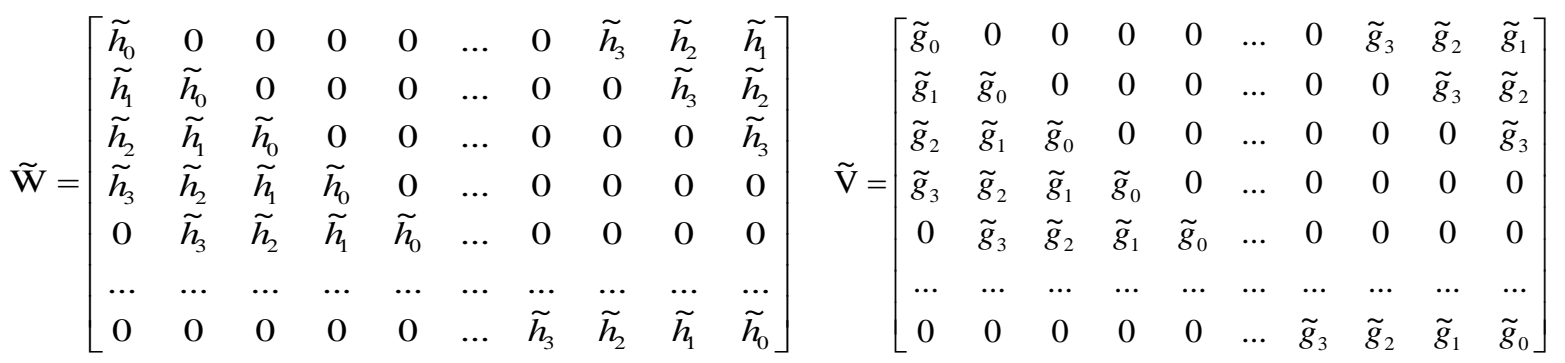




\subsection{Model Runtun Waktu Wavelet}

Peramalan data deret waktu yang dihasilkan dengan menggunakan wavelet adalah peramalan dengan menggunakan data yang telah mengalami pra pemrosesan melalui transformasi wavelet sehingga dapat dilakukan peramalan data dengan baik (Suhartono, dkk, 2010). Dalam penggunaannya, data dimodelkan dengan menginput lag pada model ARIMA menggunakan koefisien wavelet dan skala dengan rumus sebagai berikut:

$$
\mathrm{X}=\tilde{\mathrm{W}}^{\mathrm{T}} \tilde{\mathrm{w}}=\sum_{n=0}^{N-1} \widetilde{\mathrm{w}}_{n} \tilde{\mathrm{W}}_{n}=\sum_{j=1}^{J} \tilde{\mathrm{W}}_{j}^{T} \widetilde{\mathrm{w}}_{j}+\tilde{\mathrm{V}}_{J}^{T} \widetilde{\mathrm{v}}_{J}
$$

dengan :

$$
\begin{array}{ll}
\mathrm{X} & \text { : data berukuran } \mathrm{nx} 1 \\
\widetilde{\mathrm{W}}_{\tilde{\mathrm{W}}} & \text { : koefisien MODWT berukuran nx1 } \\
\tilde{\mathrm{W}}_{\mathrm{j}} & \text { : matriks transformasi MODWT berukuran nxn } \\
\tilde{\mathrm{V}}_{\mathrm{J}} & \text { : matriks transformasi MODWT pada level ke } \mathrm{j} \\
\widetilde{\mathrm{W}}_{\mathrm{j}} & : \text { koefiss transformasi MODWT pada level ke } \mathrm{J} \\
\tilde{\mathrm{V}}_{\mathrm{J}} & : \text { koefisien MODWT pada level ke J }
\end{array}
$$

\subsection{Multiscale Autoregressive}

pemodelan wavelet Multiscale Autoregressive adalah Model yang diadaptasi dari model runtun waktu AR dengan input yang digunakan adalah koefisien wavelet dan skala yang diperoleh dengan mendekomposisi menggunakan maximum overlap discrete wavelet transformation (MODWT). persamaan dari Multiscale Autoregressive adalah sebagai berikut:

$$
\hat{\mathrm{X}}_{t+1}=\sum_{j=1}^{J} \sum_{k=1}^{A_{j}} \hat{a}_{j, k} \tilde{\mathrm{w}}_{j, t-2^{j}(k-1)}+\sum_{k=1}^{A_{j+1}} \hat{a}_{j+1, k} \tilde{\mathrm{v}}_{j, t-2^{j}(k-1)}
$$

dengan :

$\hat{\mathrm{X}} \quad$ : nilai prediksi dari $\mathrm{X}$

$\hat{a} \quad$ : parameter yang ditaksir

$A_{j} \quad$ : banyaknya koefisien yang terpilih pada setiap $\mathrm{j}$

$\widetilde{\mathrm{W}} \quad$ : koefisien wavelet MODWT

$\tilde{\mathrm{v}} \quad$ : koefisien skala MODWT

Pengambilan banyaknya koefisien yang terpilih pada setiap $\mathrm{j}$ lompat sebanyak $2^{\mathrm{j}}$ karena untuk menghindari adanya multikolinieritas akibat perhitungan dari setiap pergeseran interval waktu saat dilakukan MODWT (Suparti, dkk, 2018).

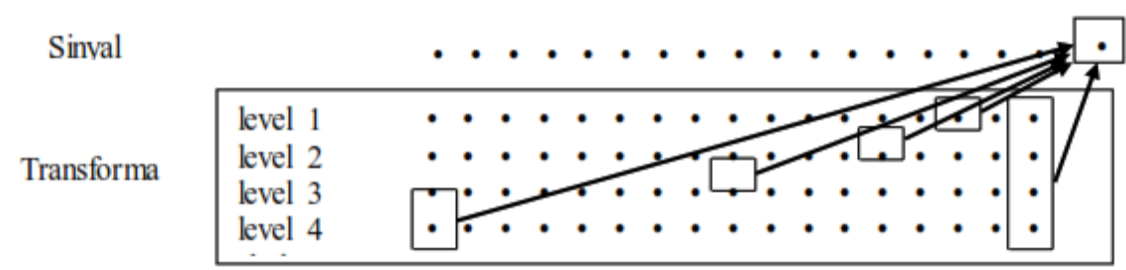

Gambar 1 Koefisien Wavelet dan Skala yang Terpilih Untuk Prediksi Pada J=4 dan Aj=2 
Pemilihan model terbaik MAR yang teridentifikasi diawali dengan uji asumsi yang terdiri dari uji normalitas residual, nonautokorelasi residual, dan homoskedastisitas residual, kemudian menghitung nilai RMSE, AIC atau SIC masing-masing model. Model terbaik adalah model yang memenuhi semua asumsi dan memiliki RMSE, AIC, atau SIC terkecil.

\subsection{Evaluasi Kinerja Model}

Evaluasi kinerja model menggunakan nilai MAPE (Mean Absolute Percentage Error) data out sample. MAPE yaitu persentase rata-rata nilai absolut error dibagi data aktualnya yang dirumuskan sebagai berikut:

$$
M A P E=\sum_{i=1}^{n} \frac{\left|\frac{y_{i}-y_{i}}{y_{i}}\right|}{n} \times 100 \%
$$

Nilai MAPE adalah MAPE < $10 \%$ berarti model memiliki kemampuan peramalan yang sangat baik, $10 \% \leq$ MAPE $<20 \%$ berarti model memiliki kemampuan peramalan yang baik, $20 \% \leq$ MAPE $<50 \%$ berarti model memiliki kemampuan peramalan cukup baik, dan MAPE $>50 \%$ berarti model memiliki kemampuan peramalan yang buruk (Chen et al., 2003).

\subsection{Graphical User Interface (GUI) Program R}

Pembuatan Graphical User Interface pada penelitian ini menggunakan paket Shiny program R. Shiny terdiri dari dua komponen yaitu User Interface (UI), dan Server. Pada bagian User Interface bermanfaat untuk panel kontrol, pemasukan nilai input, dan penyajian output. Server pada shiny merupakan otak dari program yang bertugas melakukan simulasi, berbagai analisis data sesuai pilihan pengguna dan selanjutnya mengirim hasilnya ke bagian output (Tirta, 2014).

\section{METODE PENELITIAN}

\subsection{Sumber Data dan Variabel Penlitian}

Data yang digunakan dalam penelitian ini adalah data sekunder yang bersumber dari database harga saham BBRI milik id.investing.com. Data yang didapat merupakan data time series harga saham harian BBRI periode 19 Maret 2020 sampai 23 Maret 2021 sebanyak 211 data in sample yang digunakan untuk pemodelan MAR dan menentukan model terbaik dari beberapa model MAR, sementara 31 data out sample digunakan untuk mengevaluasi kinerja model untuk digunakan sebagai model peramalan.

\subsection{Langkah-langkah Analisis}

Dalam penelitian ini menggunakan software R 3.6.2 dengan bantuan GUI R dari paket Shiny. Adapun tahapan analisis data sebagai berikut:

1. Menyiapkan aplikasi GUI R sesuai dengan kebutuhan analisis.

2. Menentukan data in sample dan out sample dan melakukan eskplorasi data.

3. Menentukan filter wavelet dan level dekomposisi J.

4. Menentukan model MAR.

5. Menentukan model terbaik dengan Root Mean Square Error (RMSE).

6. Cek asumsi dan kinerja setiap model terbaik MAR 
7. Melakukan forecasting harga saham yang akan datang menggunakan model MAR terbaik.

\section{HASIL DAN PEMBAHASAN}

\subsection{Pembuatan dan Penggunaan GUI R}

Pembuatan GUI R meliputi bagian user interface yang mengatur penempatan input dan output menggunakan perintah ui<-fluidPage(). Proses pengolahan yang dijalankan oleh GUI akan didefinisikan dalam fungsi shinyApp yaitu pada server. Berikut tampilan program UI dan server:
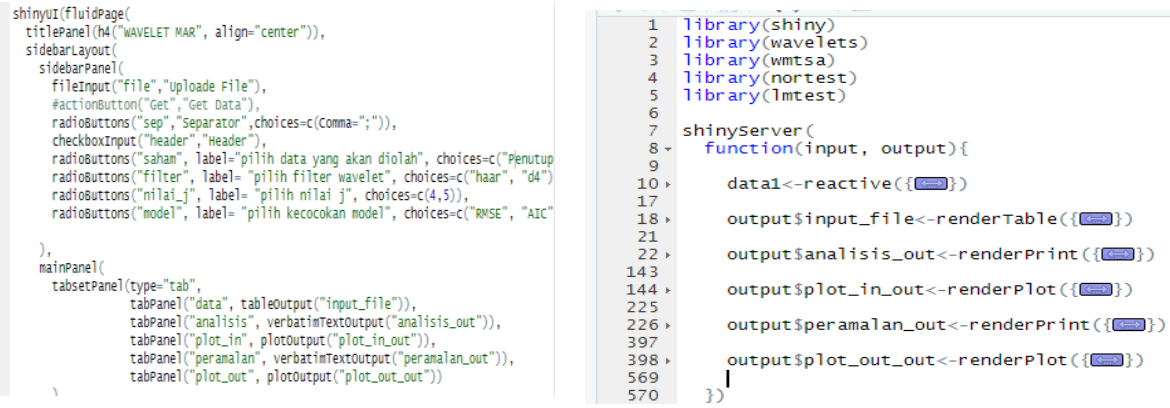

Gambar 2 Tampilan Program UI dan Server

Setelah objek UI dan server selesai dibentuk maka langkah selanjutnya yaitu running aplikasi dengan fungsi shinyApp(ui,server) dan aplikasi dapat dipakai. Berikut tampilan GUI untuk pencarian model MAR:

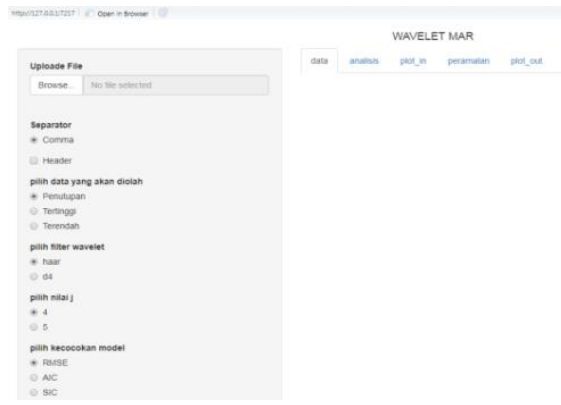

Gambar 3 Tampilan GUI R Multiscale Autoregressive

\subsection{Pemodelan Multiscale Autoregressive}

Data in sample terlebih dahulu dilakukan transformasi wavelet MODWT. Hasil dari transformasi tersebut akan digunakan sebagai pemodelan MAR. Berdasarkan hasil pemodelan MAR untuk masing-masing harga saham, diperoleh bahwa model MAR dengan filter wavelet haar dan nilai $\mathrm{J}=5$ merupakan model terbaik untuk harga saham penutupan, harga saham tertinggi dan harga saham terendah dengan nilai RMSE sebesar 87,77, 73,48 dan 81,01 serta pengujian asumsi-asumsinya terpenuhi. Berikut tabel nilai RMSE, AIC dan SIC serta hasil asumsi-asumsi untuk semua model MAR pada masing-masing harga saham. 
Tabel 1 Nilai RMSE, AIC, SIC dan Hasil Asumsi Untuk Semua Model MAR Pada Saham Penutupan

\begin{tabular}{|c|c|c|c|c|c|c|c|}
\hline \multicolumn{2}{|c|}{ Model MAR } & RMSE & AIC & SIC & $\begin{array}{l}\text { Normalitas } \\
\text { Residual } \\
\end{array}$ & $\begin{array}{l}\text { Non } \\
\text { Autokorelasi }\end{array}$ & $\begin{array}{l}\text { Homoskeda } \\
\text { stisitas }\end{array}$ \\
\hline \multirow{2}{*}{$\begin{array}{c}\text { wavelet } \\
\text { haar }\end{array}$} & $\mathrm{J}=4$ & 91,92 & 8529,82 & 8666,41 & terpenuhi & Terpenuhi & terpenuhi \\
\hline & $\mathrm{J}=5$ & 87,73 & 7770,25 & 7894,67 & terpenuhi & Terpenuhi & $\begin{array}{l}\text { terpenuhi } \\
\text { tidak }\end{array}$ \\
\hline \multirow{2}{*}{$\begin{array}{c}\text { wavelet } \\
\text { d4 }\end{array}$} & $\mathrm{J}=4$ & 228,72 & 52810,22 & 53655,84 & terpenuhi & tidak terpenuhi & $\begin{array}{l}\text { terpenuhi } \\
\text { tidak }\end{array}$ \\
\hline & $J=5$ & 257,44 & 66905,77 & 67977,09 & terpenuhi & tidak terpenuhi & terpenuhi \\
\hline
\end{tabular}

$$
\begin{aligned}
& \text { Model MAR untuk harga saham penutupan yang terbentuk adalah: } \\
& \begin{aligned}
\hat{\mathrm{X}}_{\mathrm{t}+1} & =1,1 \mathrm{w}_{1, t}+0,217 \mathrm{w}_{1, t-2}+0,884 \mathrm{w}_{2, t}+0,012 \mathrm{w}_{2, t-4}+0,928 \mathrm{w}_{3, t}-0,223 \mathrm{w}_{3, t-8} \\
& +1,003 \mathrm{w}_{4, t}-0,063 \mathrm{w}_{4, t-16}+1,013 \mathrm{w}_{5, t}-0,036 \mathrm{w}_{5, t-32}+1,007 \mathrm{v}_{5, \mathrm{t}}-0,003 \mathrm{v}_{5, t-32}
\end{aligned}
\end{aligned}
$$

Tabel 2 Nilai RMSE, AIC, SIC dan Hasil Asumsi Untuk Semua Model MAR Pada Saham Tertinggi

\begin{tabular}{clllllll}
\hline \multicolumn{2}{c}{ Model MAR } & RMSE & AIC & SIC & Residual & $\begin{array}{l}\text { Autokorelasi } \\
\text { Ausitas }\end{array}$ \\
\hline $\begin{array}{c}\text { Wavelet } \\
\text { haar }\end{array}$ & $\mathrm{J}=4$ & 78,40 & 6201,83 & 6301,14 & terpenuhi & Terpenuhi & terpenuhi \\
& $\mathrm{J}=5$ & 73,48 & 5450,88 & 5538,16 & terpenuhi & Terpenuhi & $\begin{array}{l}\text { terpenuhi } \\
\text { tidak }\end{array}$ \\
$\begin{array}{c}\text { Wavelet } \\
\text { d4 }\end{array}$ & $\mathrm{J}=4$ & 237,91 & 57140,27 & 58055,23 & terpenuhi & tidak terpenuhi & $\begin{array}{l}\text { terpenuhi } \\
\text { tidak }\end{array}$ \\
\end{tabular}

Model MAR untuk harga saham tertinggi yang terbentuk adalah:

$$
\begin{aligned}
\hat{\mathrm{X}}_{\mathrm{t}+1} & =1,676 \mathrm{w}_{1, t}+0,331 \mathrm{w}_{1, t-2}+0,692 \mathrm{w}_{2, t}+0,149 \mathrm{w}_{2, t-4}+1,016 \mathrm{w}_{3, t}-0,013 \mathrm{w}_{3, t-8} \\
& +0,898 \mathrm{w}_{4, t}-0,021 \mathrm{w}_{4, t-16}+0,975 \mathrm{w}_{5, t}-0,021 \mathrm{w}_{5, t-32}+1,004 \mathrm{v}_{5, \mathrm{t}}-0,0001 \mathrm{v}_{5, t-32}
\end{aligned}
$$

Tabel 3 Nilai RMSE, AIC, SIC dan Hasil Asumsi Untuk Semua Model MAR Pada Harga Terendah

\begin{tabular}{cccccccl}
\hline Model MAR & RMSE & AIC & SIC & $\begin{array}{l}\text { Normalitas } \\
\text { Residual }\end{array}$ & $\begin{array}{l}\text { Non } \\
\text { Autokorelasi }\end{array}$ & $\begin{array}{l}\text { Homoskeda } \\
\text { stisitas }\end{array}$ \\
\hline $\begin{array}{c}\text { wavelet } \\
\text { haar }\end{array}$ & $\mathrm{J}=4$ & 84,54 & 7215,37 & 7330,91 & terpenuhi & Terpenuhi & $\begin{array}{l}\text { tidak } \\
\text { terpenuhi } \\
\text { tidak }\end{array}$ \\
& 81,01 & 6625,76 & 6731,85 & terpenuhi & Terpenuhi & $\begin{array}{l}\text { terpenuhi } \\
\text { tidak }\end{array}$ \\
$\begin{array}{c}\text { wavelet } \\
\text { d4 }\end{array}$ & $\mathrm{J}=4$ & 222,61 & 50028,35 & 50829,42 & terpenuhi & tidak terpenuhi & $\begin{array}{l}\text { terpenuhi } \\
\text { tidak }\end{array}$ \\
\hline
\end{tabular}

Model MAR untuk harga saham terendah yang terbentuk adalah:

$$
\begin{gathered}
\hat{\mathrm{X}}_{\mathrm{t}+1}=1,353 \mathrm{w}_{1, t}-0,076 \mathrm{w}_{1, t-2}+0,789 \mathrm{w}_{2, t}-0,124 \mathrm{w}_{2, t-4}+1,017 \mathrm{w}_{3, t}-0,332 \mathrm{w}_{3, t-8} \\
+1,055 \mathrm{w}_{4, t}-0,082 \mathrm{w}_{4, t-16}+1,043 \mathrm{w}_{5, t}-0,046 \mathrm{w}_{5, t-32}+1,012 \mathrm{v}_{5, \mathrm{t}}-0,008 \mathrm{v}_{5, t-32}
\end{gathered}
$$

\subsection{Evaluasi Kinerja Model Terbaik}


Secara visual model terbaik MAR pada masing-masing harga saham menghasilkan plot estimasi yang baik untuk data in sample maupun out sample. Nilai MAPE out sample sebesar $1,194 \%$ untuk harga saham penutupan, $1,283 \%$ untuk harga saham tertinggi, $1,141 \%$ untuk harga saham terendah. Nilai MAPE kurang dari $10 \%$ menunjukkan model memiliki kemampuan peramalan yang sangat baik. Berikut adalah plot hasil prediksi MAR dengan wavelet haar $\mathbf{J}=$ 5 untuk masing-masing harga saham pada data in sample dan data out sample
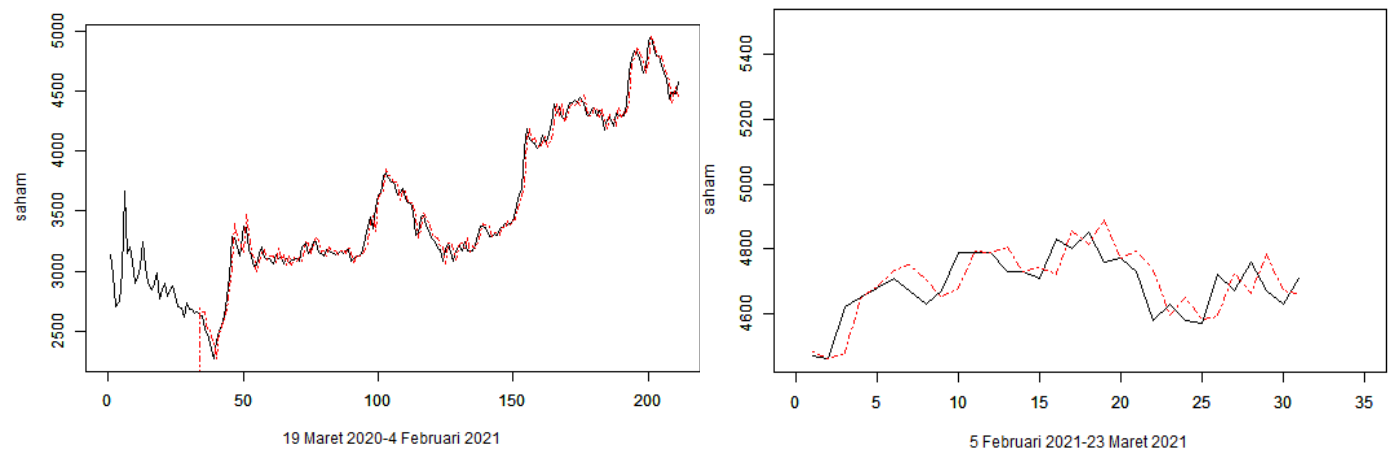

Gambar 4 Plot Perbandingan Hasil Prediksi MAR Dengan Wavelet Haar J = 5 Harga Penutupan Untuk Data In Sample dan Data Out Sample
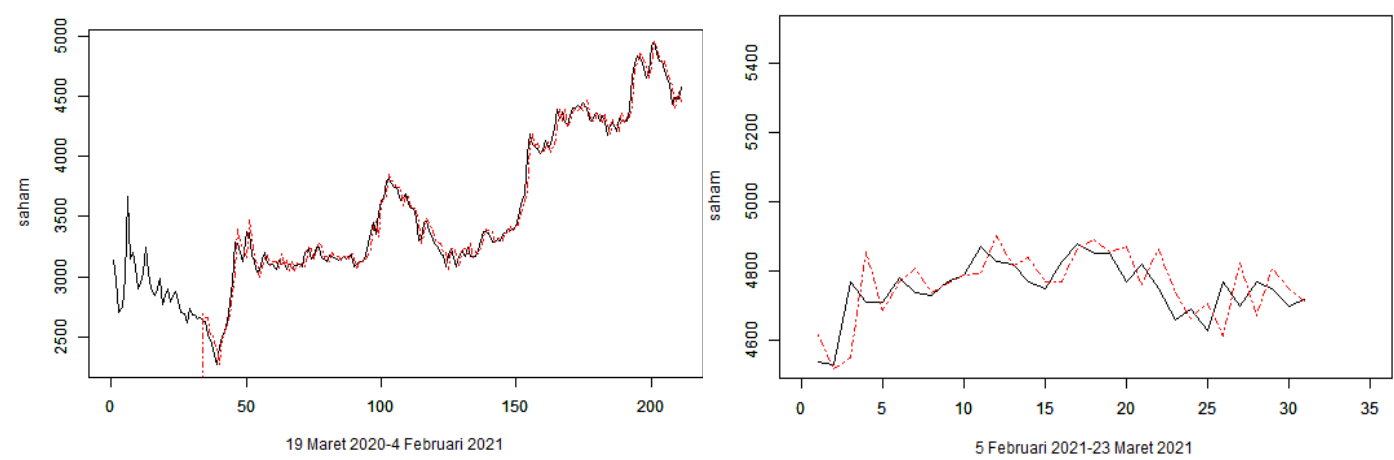

Gambar 5 Plot Perbandingan Hasil Prediksi MAR Dengan Wavelet Haar J = 5 Harga Tertinggi Untuk Data In Sample dan Data Out Sample
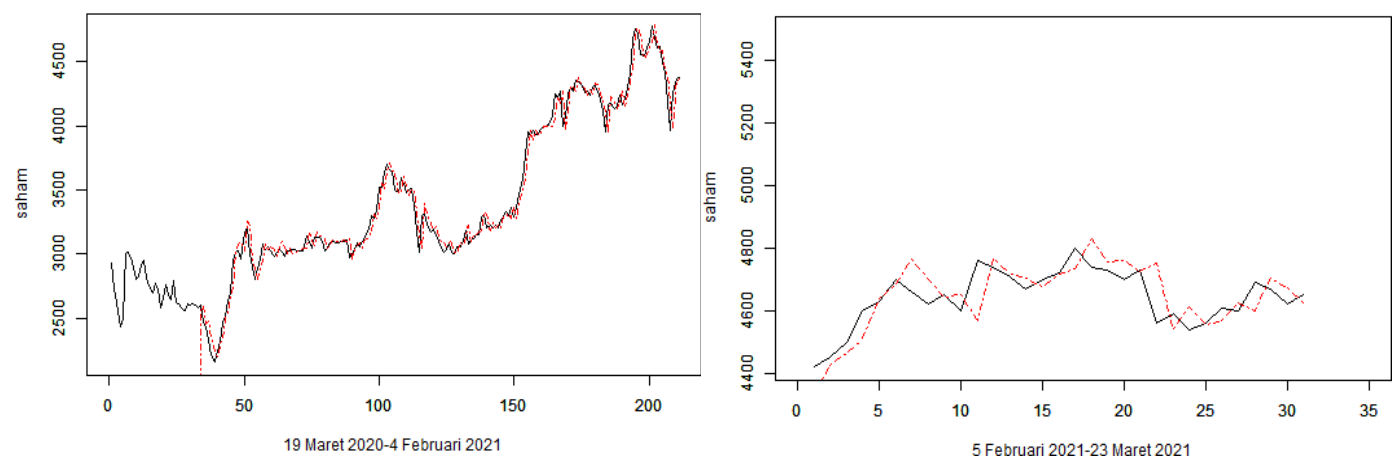

Gambar 6 Plot Perbandingan Hasil Prediksi MAR Dengan Wavelet Haar J = 5 Harga Terendah Untuk Data In Sample dan Data Out Sample

\subsection{Forecasting Harga Saham}


Forecasting dilakukan untuk mengetahui nilai harga saham yang akan datang menggunakan model MAR terbaik yang telah dilakukan evaluasi kinerjanya sehingga hasil forecasting akurat. Berikut adalah tabel data aktual harga saham dan hasil forecasting masingmasing harga saham untuk 31 hari kedepan:

Tabel 4 Forecasting Setiap Harga Saham Untuk 31 Hari Kedepan

\begin{tabular}{|c|c|c|c|c|c|c|}
\hline Tanggal & $\begin{array}{c}\text { Harga } \\
\text { Penutupan } \\
\text { Aktual } \\
\end{array}$ & $\begin{array}{c}\text { Forecasting } \\
\text { Harga } \\
\text { Penutupan } \\
\end{array}$ & $\begin{array}{c}\text { Harga } \\
\text { Tertinggi } \\
\text { Aktual }\end{array}$ & $\begin{array}{c}\text { Forecasting } \\
\text { Harga } \\
\text { Tertinggi } \\
\end{array}$ & $\begin{array}{c}\text { Harga } \\
\text { Terendah } \\
\text { Aktual }\end{array}$ & $\begin{array}{c}\text { Forecsting } \\
\text { Harga } \\
\text { Terendah } \\
\end{array}$ \\
\hline 05/02/2021 & 4470 & 4479,722 & 4540 & 4617,772 & 4420 & 4333,804 \\
\hline $08 / 02 / 2021$ & 4460 & 4462,107 & 4530 & 4517,369 & 4450 & 4424,787 \\
\hline 09/02/2021 & 4620 & 4476,446 & 4770 & 4548,594 & 4500 & 4463,728 \\
\hline $10 / 02 / 2021$ & 4650 & 4644,593 & 4710 & 4855,05 & 4600 & 4506,209 \\
\hline $11 / 02 / 2021$ & 4680 & 4681,965 & 4710 & 4685,688 & 4630 & 4639,978 \\
\hline $15 / 02 / 2021$ & 4710 & 4733,581 & 4780 & 4769,458 & 4700 & 4687,192 \\
\hline $16 / 02 / 2021$ & 4670 & 4750,098 & 4740 & 4809,683 & 4660 & 4767,09 \\
\hline $17 / 02 / 2021$ & 4630 & 4702,364 & 4730 & 4738,523 & 4620 & 4699,13 \\
\hline $18 / 02 / 2021$ & 4670 & 4648,307 & 4770 & 4766,15 & 4650 & 4641,068 \\
\hline $19 / 02 / 2021$ & 4790 & 4679,328 & 4790 & 4787,946 & 4600 & 4651,269 \\
\hline $22 / 02 / 2021$ & 4790 & 4793,211 & 4870 & 4793,109 & 4760 & 4567,931 \\
\hline $23 / 02 / 2021$ & 4790 & 4786,065 & 4830 & 4901,836 & 4740 & 4769,816 \\
\hline $24 / 02 / 2021$ & 4730 & 4803,726 & 4820 & 4817,721 & 4710 & 4718,841 \\
\hline $25 / 02 / 2021$ & 4730 & 4729,806 & 4770 & 4840,566 & 4670 & 4703,34 \\
\hline 26/02/2021 & 4710 & 4740,205 & 4750 & 4767,642 & 4700 & 4676,039 \\
\hline $01 / 03 / 2021$ & 4830 & 4719,658 & 4830 & 4767,555 & 4720 & 4715,997 \\
\hline $02 / 03 / 2021$ & 4800 & 4856,106 & 4880 & 4863,484 & 4800 & 4733,454 \\
\hline 03/03/2021 & 4850 & 4811,977 & 4850 & 4891,818 & 4740 & 4829,236 \\
\hline $04 / 03 / 2021$ & 4760 & 4887,213 & 4850 & 4855,502 & 4730 & 4758,183 \\
\hline 05/03/2021 & 4770 & 4770,999 & 4770 & 4870,273 & 4700 & 4760,926 \\
\hline 08/03/2021 & 4730 & 4794,289 & 4820 & 4761,121 & 4730 & 4723,826 \\
\hline 09/03/2021 & 4580 & 4737,087 & 4750 & 4863,378 & 4560 & 4750,568 \\
\hline $10 / 03 / 2021$ & 4630 & 4594,147 & 4660 & 4736,462 & 4590 & 4542,045 \\
\hline $12 / 03 / 2021$ & 4580 & 4651,429 & 4690 & 4665,032 & 4540 & 4612,201 \\
\hline $15 / 03 / 2021$ & 4570 & 4580,656 & 4630 & 4710,057 & 4560 & 4555,714 \\
\hline $16 / 03 / 2021$ & 4720 & 4592,175 & 4770 & 4611,414 & 4610 & 4567,288 \\
\hline $17 / 03 / 2021$ & 4670 & 4727,182 & 4700 & 4822,985 & 4600 & 4625,138 \\
\hline $18 / 03 / 2021$ & 4760 & 4663,079 & 4770 & 4672,118 & 4690 & 4599,119 \\
\hline $19 / 03 / 2021$ & 4670 & 4783,617 & 4750 & 4810,301 & 4670 & 4703,94 \\
\hline $22 / 03 / 2021$ & 4630 & 4668,678 & 4700 & 4748,444 & 4620 & 4673,92 \\
\hline $23 / 03 / 2021$ & 4710 & 4659,776 & 4720 & 4716,069 & 4650 & 4625,59 \\
\hline
\end{tabular}




\section{KESIMPULAN}

Berdasarkan analisis dan pembahasan yang telah dibahas sebelumnya dapat disimpulkan sebagai berikut:

1. Pada evaluasi kinerja model terbaik untuk masing-masing harga saham menggunakan MAPE out sample yang dihitung berdasarkan data aktual out sample dan data estimasinya menghasilkan nilai MAPE sebesar $1,194 \%$ untuk harga saham penutupan, $1,283 \%$ untuk harga saham tertinggi, $1,141 \%$ untuk harga saham terendah, yang mana termasuk dalam kategori model yang memiliki kemampuan peramalan yang sangat baik.

2. Berdasarkan hasil forecasting pada model terbaik dari setiap harga saham, harga saham terendah terdapat pada tanggal 5 Februari 2021 dengan harga 4333,804 sehingga investor dapat membeli saham pada hari tersebut. Sedangkan hasil forecasting pada harga tertinggi, harga tertinggi terdapat pada hari ke 12 tanggal 23 Februari 2021 dengan harga 4901,836 sehingga investor dapat menjual saham pada hari tersebut.

3. Pembuatan Graphical User Interface (GUI) program R pada penelitian ini merupakan pengembangan penelitian sebelumnya untuk metode nonparametrik polinomial lokal runtun waktu. Pembuatan GUI R dapat memudahkan proses input data dan running program serta memudahkan dalam menganalisis data dan mengambil kesimpulan.

\section{DAFTAR PUSTAKA}

Chen, R. J., Bloomfield, P., and Fu, J. S., 2003. An Evaluation of Alternative Forecasting Methods to Recreation Visitation. Journal of Leisure Research Vol.35 No.4: hal. 441454.

Lestari, V. N., dan Subanar. 2015. Transformasi Wavelet Diskret Untuk Data Time Series. Seminar Nasional Matematika dan Pendidikan Matematika UNYShal. 11.

Percival, D. B., \& Walden, A. T. 2000. Wavelet methods for time series analysis. Cambridge university press Vol. 4

Suhartono, Ulama, B. S.S., dan Endharta, A. 2010. Seasonal Time Series Data Forecasting by Using Neural Network Multiscale Autoregresive Model.American Journalof Applied Sciences vol.7, no.10:hal.1373-1378.

Suparti, Santoso, R., Prahutama, A., Yasin, H. dan Devi, A. R. 2018. Analisis Data Inflasi Indonesia Menggunakan Metode Fourierdan Wavelet Multiscale Autoregresive. Seminar Nasional Variansi.

Tandelilin, E. 2010. Portofolio dan Investasi (Teori dan Aplikasi). Yogyakarta: Kanisius.

Tirta, I. M. 2014. Pengembangan E-Modul Statistika Terintegrasi dan Dinamik dengan RShiny dan mathJax. Prosiding Seminar Nasional Matematika Universitas Jember hal.223-232.

Zuliarni, S.2012. Pengaruh Kinerja Keuangan Terhadap Harga Saham Pada Perusahaan Mining and Mining Service Di Bursa Efek Indonesia (BEI).Jurnal Aplikasi Bisnis Vol. 3, No. 1: Hal.36-48. 